\title{
Touchstone: Finding a Lump in the Breast
}

\author{
Susan Underwood \\ University of Victoria
}

\section{The Contours of Mortality-Finding a Lump}

we never spoke at your deathbed of your death

but from here on

I want more crazy mourning, more howl, more keening

(Rich, 1984)

The only deaths by which we are not surprised belong to the dead. The day on which we were born is marked on the calendar, anticipated, and celebrated each year, its knownness and season a part of our childhood that lingers within our adult memory. What cannot be marked on the calendar, anticipated, or celebrated is the day on which we die. Our own mortality, in spite of all hints and foreshadowings, is hidden from view until one day it surprises us, catching us suddenly and startlingly by the back of the neck, forcing us to turn and stare straight in its eye. In what shape, what colors, what sounds and textures does such a recognition appear? How does it speak? What does it say?

The doctor moves her fingers lightly over the skin of my right breast; her tone of voice and the movement of her fingers are cheerful, confident. She skims my left breast deftly and her touch falters, hesitates, no longer sure. I know the language of that touch. My own fingers stumbled like that as well, surprised when they met, instead of the expected smooth softness, a hard resistant lump, as inert and lifeless as the sound of its name.

She is careful now and thorough. She asks many questions. I answer carefully, thoroughly. I had expected this. My husband, in his efforts to reassure me or perhaps himself, had insisted that this visit to the doctor would end in an acknowledgment that everything was normal, but I knew that this would not be so. Indeed, I remember as my fingers returned after that first discovery to search the contours of this new, round presence, the knowledge shot like light through every vein, into the marrow of all my bones, that what I had searched for every few months or so for the last 10 years had at last been found. I never knew what I was looking for, I dreaded the search, yet here I 
was, successful in a way, standing in full recognition of my discovery, moaning through my whole body.

Some people are never introduced to their own mortality. "She died in her sleep; a blessing." "They never knew what hit them." "It was an easy death; he never felt a thing." We count those as the lucky ones, the ones who escape pain and slip from life unaware. But as Lorde (1980) reflected on the implications of her breast cancer:

What is there possibly left for us to be afraid of, after we have dealt face to face with death and not embraced it? Once I accept the existence of dying, as a life process, who can ever have power over me again? (p. 25)

To walk with an awareness of mortality within one's steps, to learn that a stranger is dwelling within one's body, is to look at that body anew. How could it have been known in the past if this deadly presence seems so comfortable, so quiet, so assured within? My mortality is round and small and located in my left breast. That breast, this body, have been changed forever. Wherein lies the difference? How do I live in this world in a new way?

\section{The Body as Separate from Being}

Finding a lump in my breast does not mean I have cancer; in fact, fewer than $20 \%$ of all lumps are cancerous. However, finding a lump in my breast jars me into an awareness that I may have cancer, that statistics are meaningless abstractions. Touching a lump in the breast at first dazes and numbs all other senses, pushes all cold numbers and odds from consciousness, then centers all feeling and thought on one question: What does this mean? Life is turned upside down as though someone had casually upended an hourglass to watch how the sand sifts into a new pattern. From the moment I touched a lump in my breast, I felt heavier, weighted. I moved through the day slowly, as though wading through thigh-high water, trailing my fingers in my body's wake.

Within me, a lump, dormant as a cave-bound dragon, threatened to tear me in two at any moment. I could not feel or think or move with any lightness. My body was drained of all its will and spontaneity. I told it what to do, how to act, and like a well-mannered but spiritless child, it obeyed, rising each morning to go to school, coming home each evening to go to sleep. I told it to smile, to eat, to respond to questions. 
"Body" carried a new meaning for me as an entity separate from self, something to be filled, possibly with an element of great density and unknown properties.

\section{The Body as Dwelling Place}

As van den Berg (1980) states,

The healthy person is allowed to be his body and he makes use of this right eagerly: he is his body. Illness disturbs this assimilation. Man's body becomes foreign to him. An intruder makes it his headquarters and it becomes uninhabitable to the sick person.... The body has become unfaithful. (p. 66)

To the healthy person, the body is a habit. We inhabit our bodies, dwell within them, in the sense that Heidegger (1977) speaks of when he says "To dwell, to be set at peace, means to remain at peace within the free, the preserve, the free sphere that safeguards each thing in its essence" (p. 327). When the habit or "manner of being" is interrupted, we are no longer "at peace within the free" but are in a sense ousted from our dwellingplaces.

The year before, as I waited almost four weeks for my first biopsy, I had grown angry at my right breast because I felt as if it had in some unexpected way betrayed me, as if it had become already separate from me and had turned against me by creating this tumor which might be malignant. My beloved breast had suddenly departed from the rules we had agreed on to function by all these years. (Lorde, 1980, p. 33)

Only a few days ago this was still something I could ignore; now it permeates my whole life and, I'm afraid, controls part of it. That's ridiculous. It's a thing. It has no consciousness. Therefore, I should control it. After all, it's a small inhabiter of my body, not vice versa. (Webb, 1986, p. 17)

This small inhabiter of our bodies evicts our safeguards, exposes our essence. Suddenly we seem different from other people. Our mortality is too marked. When I tell my friend that I have to have a mammogram, I recognize the expression which crosses her face. It is the same alarm, grief, pain with which I would look at her if she were telling me this news. I have worn that look as I learned of other people's mortality-at the news of accidents and illnesses and suicides and murders. To have that look directed at oneself is like looking in a mirror and seeing a skull.

This small inhabiter of my body worries me the way a dog worries an old rug, twisting and pulling, refusing to let go. Who rightfully dwells within this body? Who will be its tenant? 
Touchstone.... touchstone is a black gritty stone once used as a testing base for metals. They would strike the metal against it and know its content purity by the mark it left. Am I the touchstone? Or am I a lump of metal? (Webb, 1986, p. 18)

Is how one faces death the measure of a person's life? "Rage, rage against the dying of the light," urges Dylan Thomas (1971, p. 162). Is it better to be stoic? I am humbled by stories of courageous deaths, by those to whom death is a lesser foe. The black children who marched against a white government. The Chinese students who stood in front of tanks. The Chilean who sang to his executioners. I am aware only to the most limited extent of the pain, the torture, the hunger, the abuse, the indignity that live throughout the world. Why does this lump depress me? Why should I not carry some small parcel of suffering without complaint?

\section{Silences and Secrets}

Your breasts/ sliced-off The scars dimmed as they would have to be years later

All the women I grew up with are sitting half-naked on rocks in sun we look at each other and are not ashamed and you too have taken off your blouse but this was not what you wanted: to show your scarred, deleted torso

I barely glance at you as if my look could scald you though I'm the one who loved you

I want to touch my fingers to where your breast had been but we never did such things

You hadn't thought everyone would look so perfect unmutilated you pull on your blouse again; stern statement:

There are things I will not share with everyone.

(Rich, 1984, pp. 250-251) 
Complaint derives from se plangere-to strike one's breast in grief, to lament (Partridge, 1966, p. 499). But this grief is silent, a secret. I hide the knowledge of this lump rather than share it. I find it hard to say, "I have a lump in my breast." Something stops me from talking about my breast in the same way that I might talk about my arm or my leg or my eye. What is the difference?

As a child I thought breasts were for the most part comfy, funny things that belonged to other people's bodies. They had nothing to do with me except for being a soft place to put my head if I sat on my mother's lap. For some reason, though, breasts were impolite. You weren't supposed to mention them.

I remember when I was four or five, waiting in the car outside Joe's garage for my father to return from the darkness into which he had disappeared. The car seat was hot and sticky and I wanted my father to come back. I left the car and sought the cool, black recess of the garage interior. Near the back, in a small office, I found my father and Joe laughing, talking together. Surrounding them were glossy photographs of half-naked women, breasts looming out of sweaters and swimsuits, pointing at me. For a moment, no one knew I was there, then Joe guffawed. My father, darting a look, turned me toward the door. He took me from the room quickly. There was something about breasts that belonged to the darkness and the world of my father and Joe. There was something I didn't know. Something that scared me. Breasts were dark secrets, not to be spoken about above a whisper.

\section{Developing Self-Consciousness}

Breast-from the Middle High German "to swell" (Partridge, 1966, p. 58). Is this the word's only significance? Around adolescence, our chests began to swell; we were "developing." Something secret was happening to us, but it was a secret that everyone knew. Every gym class I wore my white blouse to school so that I wouldn't have to change in front of the other girls, exposing this new roundness. "Development," we learned in the Becoming a Woman film that was shown to all the grade 6 and 7 girls each year, had something to do with maturing, with becoming an adult. But what were we becoming? A 34B? A 36C? A 38D? Numbers and measurements seemed particularly important in this development business. These womanly "statistics" were vital, related, it seemed, to life itself.

Breasts had other names: tits, knockers, boobs, jugs. Women as well as men used those names in a way that to me felt shameful, as though part of my body did not deserve respect but instead 
had to be treated as something ridiculous and separate. Breasts did not belong to the body in the way that arms and legs and eyes did.

Nov. 21, 1982

It's only a stupid boob, so small no one will notice it's gone. But the idea of not being able to look normal in a swimsuit, teeshirt, even bra, is appalling. Not a week ago I thought I might be ready for a close relationship. Now it's possible I could lose some of the equipment to lure with....

Who knows? Maybe this will just be a close call to make me quit joking about my flat chest. A flat chest is better than none. (Webb, 1986, p. 16)

What does this mean, to regard a part of one's body as "equipment to lure with?" How can one feel whole, autonomous, and at the same time speak of one's body always in marketable terms? Assigning an extrinsic value to the size or shape of one's breasts draws us away from our bodies as dwelling places as preserves, as free sphere(s) that safeguard each thing in its essence. Without inhabiting our bodies fully, we are vulnerable, self-conscious. Is this T-shirt too tight? Should I walk by that fire station, construction site, ball park? Am I too big? Too small?

A lump in the breast replaces those concerns, returns us to our self, from what has been imposed on us to what is most private, to what is most worthy of protection, to what is most essential.

Dec. 8, 1982

I have only a few hours left now until surgery. I have only that long to remain whole and complete, a woman still. Yes, it does feel that way. It's not an arm or leg that I face losing; it's just one breast: it's not even a very big one. But with it goes my confidence, my ability to express my sensuality, much of my hope for full and happy relationships in the future. I wonder if other women react this way: the greatest fear in my mind is not the cancer. (Webb, 1986, pp. 16-18)

\section{Fear of Losing a Breast}

At least $60 \%$ of women do not examine their breasts regularly. "I'm afraid of what I'll find.... I can't stand the thought of having my breast removed" (Boston Women's Health Collective, 1984, p. 490). Even the authors of The New Our Bodies, Ourselves admit that no one in the group writing the chapter dealing with breast cancer practices breast self-examination, despite the fact that two of the writers have had mastectomies. 
In most women's minds, a lump means cancer and cancer means losing a breast. To many women, the prospect of losing a breast is more frightening than the possibility of death from cancer.

(Boston Women's Health Collective, 1984, p. 490)

What is it about losing one's breast that frightens some women more than the prospect of death? To lose any part of one's body - an arm, a leg, an eye-is a tragic event, one which would involve massive physical readjustment and emotional trauma. But to fear the loss of one's breast is to fear the loss of something else, a feeling of womanness, of sensuality, of jouissance, of sheer embodied delight.

Woman has sex organs more or less everywhere. She finds pleasure almost anywhere. Even if we refrain from invoking the hystericization of her entire body, the geography of her pleasure is far more diversified, more multiple in its differences, more complex, more subtle, than is commonly imagined-in an imaginary rather too narrowly focused on sameness. (Irigary, 1985, p. 28)

The pleasure invoked by the soft touch of one hand or pair of lips, by the brush of breast against skin, is a sexuality that inhabits our bodies, dwells within, protecting and preserving, unlike the dark secret of Joe's garage which lies outside our bodies, snickering at our trustfulness. Jouissance is body knowledge, body being.

The sweetness of curling a baby onto one's body, greeting the milky tug at a breast, this is jouissance, this is pleasure, this is dwelling within one's body. Nursing my child, watching other mothers nurse their babes, I know the integrity of my body, I feel its trustfulness and that of the child's nourishing each other. This is good. Here in our breasts these sensations can be remembered, are part of what being a woman involves in this time, in this culture.

A lump in the breast is an intruder into this dwelling place, a voyeur. How do we deal with this breach of trust?

\section{Dealing with Essentials}

\section{I understand}

life and death now, the choices

I didn't know your choice

or how by then you had no choice

how the body tells the truth in its rush of cells

(Rich, 1984, p. 255) 
Finding a lump in the breast can be a touchstone in a woman's life. A breast is more than "equipment to lure with" or a $36 \mathrm{C}$ or a portable milk bar. It is more than a symbol of motherhood or a symbol of sexuality or a symbol of objectification and degradation. It is all that and more. Our bodies manifest our being in the world. The essentials of our living are called into question when our bodies remind us of our finitude, calling us home to dwell.

Finding a lump in the breast stills time in such a way that the relationships and connections in which I am enmeshed appear as clearly etched as strands of spiderwebs shiny with dew in the sun. I look at my son and I see him not just in the present but in the past and in the future. I remember the baby at my breast. I know the teenager with braces and a skateboard. I recognize the loving and thoughtful man. The wet towels on the bathroom floor, the empty carton of ice cream drooling on his bedside table are still there, but besides them I see as well the newborn baby's tiny fingers curved on my breast, the young boy's small hand in mine. Here is a child who is healthy and happy, with whom I share hopes and fears, who needs me to love him, to listen to him. This is essential to who I am.

Finding a lump in the breast is accepting the vulnerability of my body, its temporal nature. As slow as numbness, a desire grows to dwell in my body anew, to treat it with care. I run on warm June days for the pleasure of feeling the sun on my skin, the strengthening rhythm of my stride. Rinsing the garden soil from the new green lettuce, slipping the hot yellow cornbread out of the oven, these are essentials to who I am.

Finding a lump in the breast is learning that what Cixous (1976) states feels true to who I am:

By writing herself, woman will return to the body which has been more than confiscated from her, which has been turned into the uncanny stranger on display-the ailing or dead figure, which so often turns out to be the nasty companion, the cause and location of inhibitions. Censor the body and you censor breath and spech at the same time.

Write your self. Your body must be heard: (p. 880)

Writing "my self" as a means of freeing the body leads back into dwelling:

The word for peace, Friede, means the free, das Frye; and fry means preserved from harm and danger, preserved from something, safeguarded. To free actually means to spare. The sparing itself consists not only in the fact that we do not harm the one whom we spare. Real sparing is something positive and takes 
place when we leave something beforehand in its own essence, when we return it specifically to its essential being. (Heidegger, 1977, p. 327)

Women who find a lump in their breast, who face the fears and struggle with the anxiety that such a discovery entails, paradoxically may experience a deeper feeling of womanhood than those to whom the prospect of losing a breast is more terrifying than death. Reading through Webb's chronicle of her breast cancer and masectomy, I am struck by the empowerment engendered in her words. A woman who, on finding a lump in her breast, joked about her "flat chest" and "stupid boob," who felt on the eve of her surgery that she had only a few hours to be a "woman still," one year later could write:

I just pawed through my journal for this past year. Interesting. The insides of my head was a place where monsters lurked and craziness bounced around; where corners got rounded off from pacing; where small defenseless creatures whimpered; where black bats and white doves bounced off each other in alternate darkness and blinding brilliance. It was a place, too, where a birth happened, where a whole woman walked out of the ashes, a phoenix. Oh, I still lack a breast and wear the scar. And it will always hurt. But instead of a resident dragon, I have a mere lizard, a chameleon shuffling in an arid desert. Where once it shook the earth with a stamping foot, it scratches mutely in the dust. At least for now....

That hitchhiker I picked up months ago, the one who wore the black monk's robe and grimaced through bared teeth in a skeletal smile? He's gone too. He left his robe, a grisly reminder that I'll wear it yet. But he doesn't point out intersections to me anymore, or try to get me to take turns onto roads only he can see. I'm no longer obsessed with death; I'm no longer obsessed with living. I just do it. (Webb, 1986, pp. 32-33)

The sense of dwelling within one's body, the acceptance of one's body as good, is the true "development" process, moving beyond physical attributes to an understanding of what is essential. Finding a lump in the breast, searching for an understanding of this experience, deepens the connections to the life-world and at the same time frees us to live in this world in a new way. For once the immanence of our beings is embodied in our thoughts and actions, we no longer move in silence and fear, but with greater grace and eloquence step slowly toward our end. 


\section{References}

Boston Women's Health Collective. (1984). The new our bodies, ourselves. New York: Simon \& Schuster.

Cixous, H. (1976). The laugh of the Medusa. Signs, 1(4), 875-893.

Heidegger, M. (1977). Basic writings. New York: Harper \& Row.

Irigaray, L. (1985). This sex which is not one. Ithaca, NY: Cornell University Press.

Lorde, A. (1980). The cancer journals. San Francisco: Spinsters/aunt lute.

Partridge, E. (1966). Origins. New York: Greenwich House.

Rich, A. (1984). A woman dead in her forties. The fact of $a$ doorframe. New York: Norton.

Thomas, D. (1971). Do not go gentle into that good night. The poems of Dylan Thomas. New York: New Directions.

Van den Berg, J. (1980). The psychology of the sick bed. New York: Humanities Press.

Webb, B.J. (1986). A year with cancer: Journal excerpts. Bits of ourselves: Women's experiences with cancer. Fairbanks: Vanessa Press. 